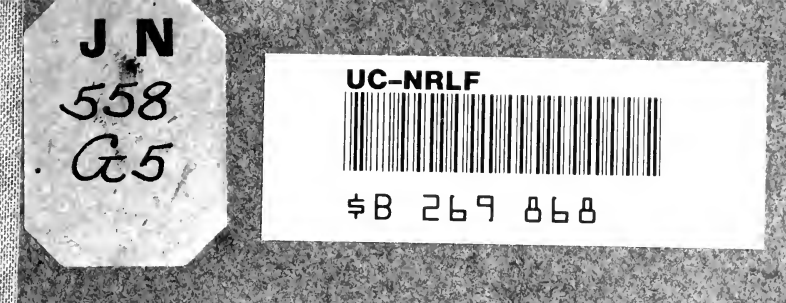




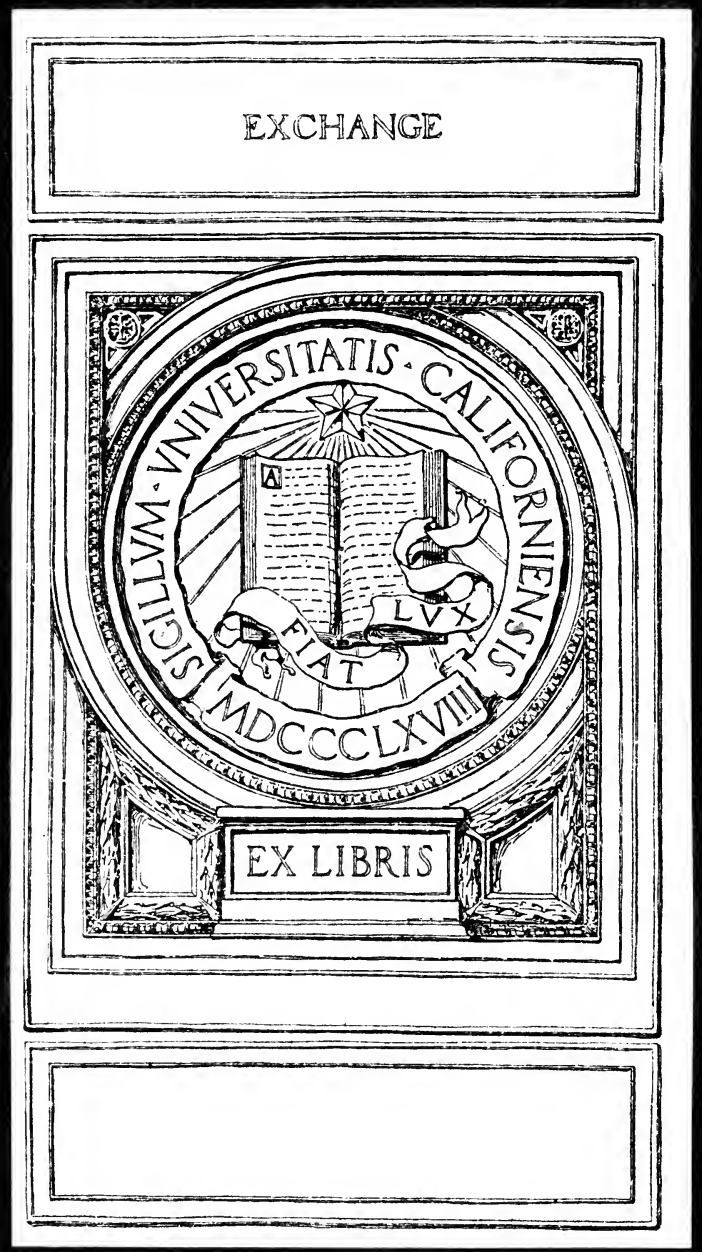


EXCHANGE

JAN $6 \quad 1915$

\title{
Ideas of
}

Political Representation

\author{
in Parliament \\ $1651-1832$
}

The Gladstone Essay 1914

BY

\section{PHILIP ARNOLD GIBBONS}

ST. JOHN'S COLLEGE

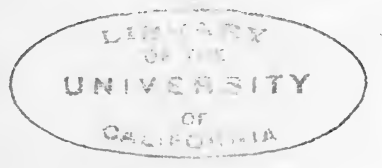

Orford

B. H. BLACKWELL, BROAD STREET 

IDEAS OF POLITICAL REPRESENTATION IN PARLIAMENT 
London Agents

SIMPKIN, MARSHALL \& CO., LIMITED 


\section{IDEAS OF \\ POLITICAL REPRESENTATION \\ IN PARLIAMENT \\ $1660-I 832$}

THE GLADSTONE ESSAY

1914

BY

PHILIP ARNOLD GIBBONS

ST. JOHN'S COLLEGE

"VIM PROMOVET INSITAM"

Oxforo

B. H. BLACKWELL, BROAD STREET

MCMXIV 


$$
\begin{array}{r}
55^{8} \\
.65
\end{array}
$$

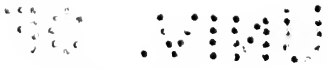

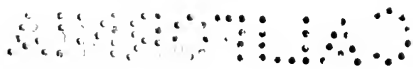




\section{SCHEME OF THE ESSAY}

\section{INTRODUCTION.}

Effect on Ideas of Political Representation of-

(a) The Postion held by the House of Commons in the Constitution and in English Political LIFE - - - $\quad$ - $\quad$ - $\quad$ - $\quad$ - 7

(b) The Representative Character of the House OF CoMmons -

(c) The Interference of the Crown in the House of Commons -

I. IDEAS OF POLITICAL REPRESENTATION

$$
\text { UP TO } 1760 .
$$

Decline of the Democratic Ideas of the Great Re-

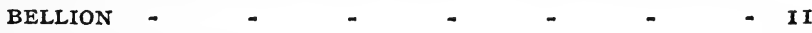
Shaftesbury's Tract Forecasts Later Whig Ideas - I3 Absence of Party Theories at the Time of the RevoLUTION

Idea of Property Qualification under William III.

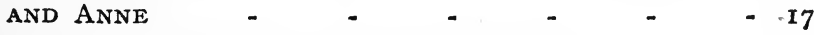
The Whig Theory of the Representative - - 20 Opposition to the Whig Theory of the Representative 23 Swift and the Tory Idea of Political Representation 25

\section{IDEAS OF POLITICAL REPRESENTATION FROM 1760 TO 1832.}

Characteristics of the Period -

The House of Commons out of Touch with the People owing to (a) INfluence of the Crown and (b) IndusTRIAL Revolution 
$\mathbf{v i}$

CONTENTS

The First Parliamentary Reformers Attack the INFLUENCE OF THE CROWN $\quad$ - $\quad$ -

The Conservative Theory of the Constitution - 33

The Liberal Whigs and the Ideas of the Reform BILl -

THE RADICALS -

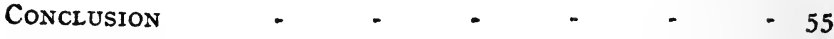




\section{Ideas of Political Representation in Parliament}

\section{From the Accession of Charles II. to the Great Reform Bill of 1832}

THE period of English History, commencing with the Restoration and ending with the Reform Bill of 1832 , is pre-eminently one in which the House of Commons, having asserted and vindicated its constitutional position, takes its place as the central figure in the political life of England. Taking the period as a whole it is safe to assert that the representatives of the people have no longer to defend themselves against any attack on their position as an integral part of the Constitution, and although it is true that under the later Stuarts the Parliament had the utmost difficulty in making good its claim to a share in the decision of national policy, and was constantly liable to have its statutes overridden by the suspending or dispensing power of the Crown, yet neither Charles II. nor James II. attempted to rule without Parliaments as their father had done, or, if such was the real policy of the latter, it had not been definitely formulated by the time of the Revolution. 
Both seem to have preferred the easier method of tampering with the elections and so controlling the House, whilst from the accession of the House of Hanover this latter expedient was the only means whereby the authority of the Crown could be increased. The position of the House of Commons in the Constitution is, then, assured, and its importance in the political life of the country is illustrated by the great attention paid by all modern histories to its debates and decisions, even to the exclusion of other important factors in national history. The House of Commons was, in fact, the central figure in England, and it is round the House as a nucleus that ideas of political representation group themselves, and become either an attempt to explain its formation or a proposal for its reform. A radical theory, however extreme it may be, nearly always looks to the reformation of the House of Commons for its fulfilment; a conservative theory will merely attempt to explain its composition from its own point of view.

Since, then, the composition of the House is of importance in any account of ideas of political representation, it is necessary to understand the relation of that composition to English society. Speaking generally, it may be said that the unrepresentative character of the House has been considerably overrated, and that on the whole it represented fairly well such public opinion as there was in England. The modern Englishman, under the influence of the almost mathematical regularity of the franchise, and the comparative equality of the constituencies, is apt 
to stand aghast at the eccentricities of both franchise and constituencies in the unreformed House of Commons; yet these very eccentricities had helped to bring the House into a very definite relation with the state of society. When the period opens, the yeoman class is still powerful, and the House of Commons still comparatively democratic, but as the former declines, so the House, by means of the rotten boroughs, falls under the control of the greater nobility, who by degrees attain an influence in the House proportionate to their influence in the country at large. It may, of course, be argued that, having once grasped political power, the nobility retained it some time after their influence in the country had been undermined by the industrial revolution, and that, had not some 'legal revolution' such as the Reform Bill deprived them of it, they might be holding it still. But the real reason for this retention of power by a class declining in its influence on society is seen by the tremendous accession to conservative and reactionary sentiment caused by the French Revolution, and before 1832 the partial repeal of the Last Determinations Act, the partial or complete disfranchisement of hopelessly corrupt boroughs, the non-partisan bestowal of the stewardship of the Chiltern Hundreds, and the revival of the feeling that members had some responsibility to their constituents and some duties in the House, all suggest that even had there been no sweeping reform in 1832 , not only would the touch of supreme authority required to remedy the grosser and more 
obvious abuses of the electoral system have been applied, but that by degrees the House would have conformed itself to the changed condition of the social system. The social system was always acting strongly, if imperceptibly, on political representations. So also it may be definitely asserted that at no time was the House of Commons unmindful of public opinion and representatives feared to incur the distrust and opposition of their constituents, illustrations of which fact will be found in the careers of all the great men of the eighteenth century. Thus, taking a general view, it may be said that the system was a good one as systems go, for it allowed free play for effective political forces. In the eighteenth century, for example, after the decline of the yeomen, there was no large class which had political aspirations and was unable to gain a hearing; any thing that deserved to be called public opinion was limited to the opinions of the gentry and the more intelligent part of the middle classes, so that in this sense the political machinery provided a sufficient channel for the really efficient forces of political thought.

This fact, which, for want of a better expression, may be called the representative character of the House of Commons, had a great effect on ideas of political representation. Theorists may desire to give greater political weight to one class than it has already, but with the exception of the Radicals, they seldom think that there are any large classes in society which ought to be, and are not, represented. Similarly they may attack rotten boroughs, but it 
seldom occurs to them to declare that through those boroughs a class has gained more political power than it should have. But to this satisfaction, if it can be so called, in the representative system, there is one great exception due to the interference of the Crown, for if the King wishes to control Parliament, almost necessarily he wishes to control it in opposition to public opinion, and at once theories spring up which seek to provide a means for the better representation of the people. So the interference of Charles II. in elections produced that interesting theory found among Shaftesbury's papers, and in the same way the interference of George III. produced those ideas of Parliamentary Reform in the direction of the better representation of public opinion, which brought that object to a position nearer to its realization than any it arrived at before the time of the Great Reform Bill. But with this exception it is fairly correct to say that from the time of the accession of Charles II. up to the Reform Bill period theories of political representation generally recognized the representative character of the House of Commons, and did not aim so much at a revolution in the representative system as at a correction of what might be considered minor faults.

In the period just before the Restoration theories had been put forward more democratic and advanced than any propounded by English thinkers for more than a century afterwards; and Cromwell had carried out a measure which effected a considerable redistribution of seats and reorganization of the franchise. 
The cause of this apparent break in the continuity of political ideas cannot be found in English society as it then was, for that society was only too ready to acquiesce in the Restoration Settlement, and must be sought in the Cromwellian army. This institution, with no particular relation to English society and tradition, drawn mainly from a particular class, and that the most radical in the country, combined with its ostensible functions that of an overgrown debating society, in which religious enthusiasm was raised to the highest point, and was admirably fitted to take the place of a forcing-house for political theory. The Levellers in the "Agreement of the People ' demanded the biennial election of representatives and the redistribution of seats. Later on they are found discussing manhood suffrage, in which connection Pettus declares that all inhabitants of the kingdom who had not lost their birthright should have an equal voice in elections; and Rainsborough explains their position by asserting that for a vote it was not necessary to possess property, for the reason which God had given to all was sufficient qualification. Even more strange and out of place were the proposals made by Harrington and his followers, which included the adoption of the principles of universal suffrage and rotation. But that these ideas were really produced by the curious condition of the army and rested on a very insecure basis in the country is evident from their complete collapse when the Restoration brought about the disbandment of the troops. In the great enthusiasm 
for the monarchy, democratic ideas were left in abeyance; nor did they revive when this first enchantment had passed away, and when the Crown and the Country Party were involved in a life-anddeath struggle. From the Restoration period the idealism of the Great Rebellion and the Protectorate is absent; it is no longer a question of setting up a Christian democracy, the kingdom of God upon earth, but the practical issue of the supremacy of Protestantism over Roman Catholics, and the very republicans themselves, as Dryden puts it, "Were for laying honest David bye,' merely on 'principles of pure, good husbandry.' A Harringtonian or two comes out of seclusion to advocate vote by ballot and rotation, but apart from this, the last really Radical idea comes from Penn and Sydney, who, in drawing up the constitution of Pennsylvania, arranged for equal electoral districts, vote by ballot, and manhood suffrage; that is, every man of twentyone years of age, and unconvicted of crime, was to be capable of electing and being elected.

The Restoration had at first much the same effect on all political theories: the Presbyterians, although they had gained nothing by the event to which they had so largely contributed, and although from their church government they had a developed representative system before their eyes, contributed no new outburst of literary activity, and Independents and Baptists were similarly silent. Yet, as the policy of Charles II. developed, and the struggle between the King and the House of Commons became more 
acute, political ideas begin to revive. Thus, in 1679 , there was brought forward a bill for the regulation of the abuses of elections, in which it was proposed that the electors of the knights of the shire should be worth $£ 200$ in fee, and that in every indenture made and sealed by any electors it should beinserted that the person or persons were authorized to serve in Parliament for the space of two years from the day of the return of the writ of summons. Such a motion as this is not to be regarded as a disfranchising act; its idea was the same as that of many Whig theorists, that is, to secure that voters shall be men of such character and property as to be independent of outside influence, whilst the idea of shortening the duration of Parliament was naturally suggested by the career of the Long Parliament of the Restoration, and was fulfilled in the Triennial Act of 1694. On the same lines, but providing a very much fuller and more interesting theory, is the tract found among Shaftesbury's papers after his death. Here he states that the design of choosing members of Parliament by the people was that no laws should be made, monies raised, nor any course pursued by those who sit at the helm, but by the steerage of the people by their representatives; for every individual person in the nation has a natural right to vote in the great council, and it is only because this is impossible that they devolve their right upon certain common representatives, among whom the whole body of the people is, or ought to be, represented. In view of the fact of the rotten boroughs, he contended that Parlia- 
ment was no equal representative of the people; the rotten boroughs, to use his own expressive phrase, ' needed a touch of the supreme authority to set them right,' and members should be taken from them and given to the larger towns and to the counties. Yet in spite of his opinions upon these points, and in spite of his advocacy of vote by ballot, Shaftesbury is not really democratic, and, as a practical working measure, he proposes to substitute for the eccentricities of the franchise a property qualification for electors equivalent in value to that of the forty shillings freehold in 1430 , and to require a proportionately larger one from candidates; his reason being that it is not safe to make over the estates of the people in trust to men who have no property of their. own, lest their property, in conjunction with an external temptation, should overcome their morality and turn them against the interests of their constituents. The great interest in the theory lies not so much in any intrinsic merit that it may have, but in the fact that in its main point of view it forecasts the attitude of the Whigs to representation during the whole of the period up to 1832 . He believes that the Constitution intended that the House of Commons should be the representative of the whole nation-in other words, that it should be a control for the people-yet, on the other hand, he will not put the franchise into the hands of the masses, who are too easily influenced by external influence to make satisfactory electors, so that the best way in which to obtain a true representation of the people will be to 
correct the anomalies of the representative system, and to have both as electors and elected men of such property as to be independent of any influence whatever. It is the attitude of the Whigs of the Reform Bill a century and a half before they carried their measure.

For the moment, however, it is impossible to say that Whigs, or, for that matter, Tories, had any ideas of political representations which belonged specifically to their own party. It is true that the Tory party is usually associated with the idea of the representation of the land, and the Whig with that of the representative as opposed to the delegated character of members of Parliament; yet, on the one hand, Locke and Defoe, as well as the Tories, insist on the representation of the landed interest; and on the other the Tories by their action in I7OI to the Kentish petitioners showed their adhesion to what is supposed to be the Whig theory. Nor was the attack on the anomalies of the representative system confined exclusively to one particular party-both are found demanding the excision of rotten boroughsand the denunciation of Locke is not more vigorous or convincing than the denunciation of Swift. In fact, as far as the two political parties were concerned, during the reigns of William III. and Anne, ideas of political representation were in the melting-pot, and although towards the end of the latter reign there are signs of party demarcation on this point, it is not until the Hanoverian period when the long Whig régime developed in that party, in spite of the fact 
that it represented the more progressive elements in the community, and owed its origin to a great struggle for political liberty, those conservative and reactionary instincts which power naturally produces, that distinctively party theories grow up. It is then that the Tories, impatient at the corruption which was one factor in depriving them of political power, unite to their conservative prejudices strong democratic sympathies, which make them for long the habitual advocates of short Parliaments, Place Bills and Pension Bills and which in Swift become a comprehensive Tory theory.

Thus, at the time of the Revolution, Shaftesbury's ideas are not adopted by either political party, although at the same time the idea of the representation of property, or at any rate, of the necessity of a property qualification for electors and elected, is taken up in many quarters. This is seen very clearly in Locke, who, as far as he can be judged from the scattered evidence in his works, followed Shaftesbury rather closely. His denuriciation of rotten boroughs in that "the bare name of a town in which there remains not so much as the ruins .... sends as many representatives to the grand assembly of lawmakers as a whole county, numerous in people and powerful in riches,' has become almost classic; and he also would seem to suggest a touch of the supreme authority, or rather of the Executive, to set them right. In the Constitutions of Carolina, Locke insists on the property qualification, and states specifically what Shaftesbury may have had in his mind 
but did not specifically state, that the elector must have real property. The Parliament is to consist of the proprietors of the colony or their deputies, the landgraves and casiques who represent the large land-owning classes, and one freeholder out of every precinct who is to be chosen by the freeholders of the said precinct. No man could be chosen a member of Parliament who had less than 500 acres of freehold within the precinct for which he was chosen; nor should any have a vote in choosing the said member that had less than fifty acres of freehold within the said precinct. A new Parliament was to be summoned every two years. One might think this insistence on real property a mere aberration in Locke's Whiggism, and a proposal made in Parliament about the year I700 seems to be much more in accordance with what are supposed to be Whig ideas. It suggested that as the assessment of two shillings in the pound had raised $£ 989,965$ from the kingdom, each member ought to be elected by a constituency paying roughly $£ \mathrm{I}, 930$, and thus it might be known whether a county was over- or under-represented: the idea obviously being that representation should be based on taxation. But that some considerable section of the Whigs really held the idea of the representation of the land is seen in some extraordinary remarks of Defoe in a Whig treatise on The Original Power of the People of England, which, if he were not quite serious in the rest of the treatise, might be taken as an attempt to reduce the theory to an absurdity He argues no person had any right 
to live in England save those to whom England belonged; that the freeholders are the proper owners of the country, and the other inhabitants only exist on sufferance; and thus the only ground upon which the towns could base their right to representation was the consent of the freeholders. He even goes on to draw the conclusion that if the King possessed all the land in England, he would be an absolute monarch, and there could be no rights against him. What conceptions could have produced a theory like this it is hard to see, but the general idea of the representation of land seems to have been derived partly perhaps from the semi-feudal idea of governmental rights attached to the possession of land, exemplified to some extent by the institution of the justices of the peace, and more immediately from a sort of physiocratic idea of land as the only basis and, indeed, the only real form of wealth, an idea which appears strongly in the Tory writers Swift and Bolingbroke. The Tories, in fact, eagerly took up the idea as a method of increasing the influence of the country gentlemen, the main support of the party. In I696 they made headway with a Bill making it a prerequisite to service in the House that a knight of the shire should have $£ 600$ a year in land, and a burgess $£ 300$; and in I7Io a measure to this effect became law. In this connection Bolingbroke is quoted as saying that the landed men were the true owners of the political vessel, and the moneyed men but passengers in it. Swift writes that the House of Commons was the best representative of the nation 
within memory, and so it had taken care by the noble Bill of Qualifications that future Parliaments should be composed of landed men, and that property should no longer be at the mercy of those who had none themselves, or at least what was only transient and imaginary; and later, "there could not be a truer maxim in our government that the possessors of the soil are the best judges of what is for the advantage of the kingdom.'

It is now time to consider a theory of political representation which, during the period under consideration, directly and indirectly, probably had a greater influence on political life than any other-the Whig theory of representation-a theory which may be said to have culminated in Burke, but yet which is found clearly stated in as early a writer as Algernon Sydney. Though Sydney considers that the legislative power that is exercised in Parliament is essentially and radically in the people from whom their delegates and representatives have their authority, yet he thinks the most certain sign of this unlimited power is that they rely upon the wisdom and fidelity of their deputies, so as to lay no restriction on them. Since at the time of the election neither elected nor electors can foresee what measures will be brought up, the former must be allowed free powers to do as they think right, and although it may be convenient for them to listen to the opinions of their constituents in order to give more weight to their opinions, they are not properly obliged to give an account of their actions. Parliament was not to be a congress of 
ambassadors of different bodies; for the powers of the cities, counties, and boroughs of England are regulated by the general law to which they all consented, and by which they are all made members of one political body. So that it is not 'for Kent, Sussex, Lewes, or Maidstone, but for the whole nation that the members chosen in those places are sent to service in Parliament.' The whole idea of the representative as opposed to the delegated character of members shows how largely the events of the last forty years had altered the character of Parliament: The struggle between the Executive and the House of Commons is now mostly over, and what takes its place until the time of the Revolution tends rather to be a struggle between the Crown and the people for the control of the House of Commons. In the short and erratic Parliaments of James I. and Charles I. one can hardly conceive of any difference of opinion arising between members and their constituents; but the careers of the Long Parliaments of the Revolution and the Restoration had brought the question into prominence, and had made some decision of it necessary. But Sydney's theory has in it more than a mere theoretical justification of existing facts or forecast in view of future conditions; it is based on an idea of the country which he put forward, and in which the later Whig writers followed him. To him England was not so much a nation as a series of communities, each with its separate objects and separate interests; and were members to be delegates, Parliament would be nothing more than the battle-ground 
of the representatives of these interests. The way out of the difficulty is that members once elected are not members for Kent, Sussex, Lewes, or whatever theirconstituency may be, but members for England; and their judgment of measures is to be decided by the national welfare, irrespective of local interests. That this theory was generally accepted by Parliament is seen in the action of the Tories to the Kentish Petitioners in I70I, and still more so in the Septennial Act of I7I5. It is, indeed, not to be supposed that the Whigs drew the logical deduction from this immense arrogation of power on the part of the Parliament, and the theoretical argument is kept hidden, while the practical inconvenience of holding an election at a time of national disturbance is emphasized; but in I735, on a motion for the repeal of the Septennial Act, the Whig idea is put forward clearly and distinctly. It is stated that although members had all a dependence on the people for their election, after they were chosen and had taken their seats in the House, the whole power of the electors was devolved upon them; so that every question was to be decided by the good judgment of the House, and with respect to the public good in general: and Sir William Yonge, speaking almost in the same words as Algernon Sydney, goes on to say that members, after taking their seats in the House, should cease to have any particular bias for the county, city, or borough they represented, should drop not only their dependence upon, but even their concern for their particular constituency, and look- 
ing on themselves as representatives of the whole body of the Commons of England, should concur with the rest of the members of the House in what they judged to be for the general interest of the nation.

It is not remarkable that this theory did not hold an unquestioned authority in English political life; no sooner is it put forward than it is combated, and the justice of its conclusions questioned. The attack on it is naturally made by means of a theory of delegation. Before Sydney had written the Discourses on Government, Andrew Marvel had kept up a relationship with his constituents in Hull by consulting them with regard to his action in all important matters, which suggested that neither he nor they would have assented to such a theory as was there put forward; and on the question of the Kentish Petitioners a number of tracts, particularly the Jus Populi Vindicatum, put forward the delegation theory with considerable force. Members, it considered, were delegated by their electors to supply their places in treating of the great and important matters which were upon the stage, in that juncture in which Parliament was summoned; but it was only upon such matters and not on others which mightarise at a later date that they were called upon to judge, for it might easily happen that a person fit to represent the electors in one juncture would be judged unfit in another. This was, in fact, an early instance of the idea of the mandate-an idea which has been frequently brought forward, even up to our own day-to combat what may be considered any undue 
arrogation of power on the part of the members against the people at large, and the writer went on to say that delegation imported in its own nature a power in the person or persons who delegate to revoke it at his or their pleasure, and it could continue no longer than during the time and particular occasions for which it was granted. The deduction drawn from this was not that members should be mere delegates, nor that there should be continual references to the people on points of importance, but annual Parliaments which would supply a sufficient remedy for the grievance without any considerable inconvenience. Curiously enough, although in this case the theory is used against the Tories, when it again appears it is employed by the Tories agairst the Whigs, in the debate on the Septennial Act, and however little one can admire their honesty, there can be no question as to the skill with which they put forward a complete theory of the position of the House of Commons in relation to the electorate, and demonstrate the logical conclusion to be drawn from the passing of the Bill. It is, in fact, from the debate on this Bill and on a motion for its repeal in 1734 that the tradition of Tory democratic sentiment, emphasized by Disraeli in later days, is drawn, and not from anything that Bolingbroke either could or would have laid down as Tory principles. Briefly put, the Tory position, as expressed in the speeches of Shippen, Snell, Hutcheson, and others, is that whilst the assent of King, Lords, and Commons was necessary for the making of laws, the Commons, 
being unable to give their personal assent to laws, constitute certain persons their attorneys with large general powers. What these attorneys do during the term of their office, no doubt will bind the Commons, but any extension of that term by themselves will be tantamount to depriving the Commons of their right of assent to bills; for on the one hand they would cease to be the trustees of the nation and become their own electors, and on the other there would be a great danger of unfaithfulness to the wishes of the people on the part of the attorneys. In I734 the theory has become even more extreme. A view of the constitution is taken up which even if it had some historical accuracy was hopelessly out of place in the eighteenth century. Lord N. Somerset declared that the House of Commons was properly the Grand Inquest of the nation, its object being to represent the grievances of the nation to their sovereign; for this object continual reference to the constituencies was necessary, and references, said the noble lord, had often been brought about by the refusal of the members to agree to the proposals of the Court until they had consulted their constituents.

Can it be said, then, that there was any Tory theory of representation, or must one conclude that these ideas-representation of the land and annual Parliaments-are merely isolated theories adopted at different times to strengthen the Tory position in Parliament or to attack the Whig theory of representation? The answer seems to be supplied by Swift, who in his short but very remarkable Essay 
on Public Absurdities, combines the extreme Tory prejudices of his time with considerable democratic sympathies and thus produces a theory which is well worth consideration. The qualifications for the franchise which the Dean wishes to impose are twonamely, membership of the Church of England and the possession of land of a certain value. He thinks that the admission of Nonconformists to the ranks of voters endangers the Church of England, and as the Church had been established by the nation, it was an absurdity to give them the franchise, in which respect he was probably voicing a strong opinion among the Tories, which had found a partial and incomplete expression in the Corporation and Occasional Conformity Acts. The land qualification was, he thinks, the meaning of the Act of 1430 , but owing to the change in the value of money the forty shilling freehold had become utterly capricious, and gave an opening for an unlimited amount of chicanery; for it, as a qualification, the Dean considers land capable of producing a certain amount of some commodity-hay, for instance-should be substituted. The members whom Swift wishes to see in Parliament are, as one would expect, the country gentlemen. Hence he blames the custom of throwing the expense of the election on the candidates, or, as was often done, on the ministry. The strongest methods should be employed to leave the electors to their own choice, which would then consist of the persons with good estates in the neighbourhood or county, who would presumably be best acquainted with the 
interests of that neighbourhood, and, at any rate, never of strangers. To choose a representative for Berwick, whose estate was 'at the Land's End' in former times, would have been considered a great solecism; but how much more so was the system then in vogue under which so many persons who did not possess a foot of land in the kingdom were returned? Finally, in his own vigorous phraseology, Swift condemns the rotten boroughs. 'It is likewise absurd that boroughs decayed are not absolutely extinguished because the returned members do, in reality, represent nobody at all, and that several large towns are not represented, though full of industrious townsmen who much advance the trade of the kingdom.' Thus, whilst insisting on freehold property and membership of the Church of England as qualifications for electors, Swift's Essay anticipates the Reform Bill in three cardinal points-the abolition of the rotten boroughs, the representation of the large town populations, and the diminution of election expenses-and partially in a fourth, the regulation of the franchise. Nor does Swift stop at this point; for in another place he gave his adhesion to the principle of annual Parliaments on the ground of the danger of the corruption of members in long Parliaments. Such a theory as this can hardly be considered to have rested on mere opposition to abuses which the Whigs were interested to maintain, nor did it arise under influence of one great central idea. It must be taken to mean that Toryism was, to some extent, opposed to the absurdities of the 
representative system, and was in this sense, if in no other, democratic.

The year I760 has been taken as a convenient point for the division of this subject. It is not that at this time there is any considerable break in ideas of political representation; on the contrary, the idea of the representation of the land and the Whig representative theory still continue in vogue among considerable sections of the community and the latter, at any rate, has yet to reach its culminating point. Yet no one who has looked into the various theories which are brought forward at this time can fail to be struck with a certain indefinable change of tone and atmosphere which commences with the accession of George III. The reign of George III. is in many ways totally different from that of his predecessor. This difference may be considered as due to one cause-the House of Commons is getting out of sympathy with the people. Want of sympathy is partially apparent in the days of Chatham. 'You have taught me,' said George II., ' to look for the sense of my people in other places than the House of Commons.' Chatham, too, had roused the spirit of the nation by his brilliant foreign policy, and this new spirit had a tendency to demand a share in the government of the country. Yet even so, it must be remembered that he had at no time any powerful family connection behind him, and that his strength lay in the middle classes, who, though mainly unrepresented, made their voices heard in Parliament. 
But Chatham's resignation was brought about by the interference in the House of a force which had so long remained in abeyance that its very existence had almost been forgotten-the influence of the Crown. For George III., ' a true Briton,' threw over at once the somnolent acquiescence with which the earlier Hanoverians had viewed the ascendency of the Whig nobles, and commenced to form a Court party under Court influence. The result was an alienation of the House of Commons from the ideas and sentiments of the community, more complete than had been witnessed in any Parliament since the Restoration, and a consequent rush of ideas of Parliamentary Reform. The obvious remedy, as was seen by Burke and others in his day, was the removal of Court influence by the abolition of corruption, and a return to the old system of virtual representation, which had up to this time worked so efficiently; but Burke had not reckoned with the far-reaching effects of economic movement. On the assumption that the House of Commons was representative of the people, one would expect the demand for Parliamentary Reform to collapse with the abolition of Crown influence; but although a decline is very evident, it does not utterly die down. The fact is, that even while the struggle against Court influence is going on, there has commenced that springing up of new industries and that shifting of populations which goes by the name of the Industrial Revolution which undermined the power of the Whig aristocracy and brought into prominence classes with political 
aspirations which had as yet no voice in the government of the country. Thus, instead of dying out, the demand for Parliamentary Reform only takes a wider and deeper significance; formerly it was expected to result in the better representation of public opinion, now it is a direct attempt at the enfranchisement of new classes.

With these considerations clearly observed, it is easy to see into what classes the main ideas of political representation fall. The Tories, raised to power under the protecting ægis of George III., are both unable and unwilling to alter the constitution of the House and leave political theories severely alone. The Whigs, conservative and liberal, advocate measures of Parliamentary Reform to secure a better basis of representation for public opinion. The Radicals demand the enfranchisement of new classes. And, as forces begin to change their position, so do ideas of political representation. On the one hand George III., after flouting public opinion in the case of the Middlesex election, subsides into comparative acquiescence with it over the American War, finally appearing as its representative against the Coalition Ministry, and, as a consequence, the first demand for Parliamentary Reform dies a natural death and is succeeded by the question of the enfranchisement of new classes. Then the French Revolution effects a complete change in political ideas, and after it has subsided leaves the Tories, with the theory which had belonged to the conservative Whigs, facing the reformers, whetherWhig or Radical, 
with the aspirations and ideas of a new England, which demanded the recognition of its capacity to a share in the government behind them.

Chatham, one of the first statesmen to suffer from the interference of the Crown in the House of Commons, was also one of the first to give his adhesion to the project of Parliamentary Reform. His ideas on the subject were not decided, and in many ways were rather retrospective than progressive; those of a better representation, for instancea representation chiefly of the land-are reminiscent of the Tories and the Revolution Whigs. Property, and, above all, landed property, 'the soil,' as he liked to call it, should be represented, and as the representation of the counties was still preserved uncorrupted, he advocated an addition to the number of county members who approached nearest to the constitutional representation of the country. The smaller boroughs he called the rotten parts of the constitution, but he was too cautious to advocate their disfranchisement. On the all-important question of shortening the duration of Parliaments he was for long undecided, the advantages of the limited influence of the Court being counterbalanced in his mind by the danger of the increase of corruption; but, as the power of the Court increased, he declared for the repeal of the Septennial Act on the ground that the influence of the Crown was so enormous that the whole Constitution was in danger. and the erection of some strong bulwark to keep it in check was a necessity. But the Septennial Act 
was not repealed, and the feeling that the House of Commons was not representative of the country continued to spread. Wyvil conceived the idea of bringing the freeholders of the county of York together to petition Parliament for reform, and the idea, when once it was conceived, rapidly spread from being merely a demand for economy to include views on shorter Parliaments, the abolition of rotten boroughs, and the extension of the suffrage. As the spokesman of this movement in Parliament, Pitt, in I782, moved for a committee to inquire into the state of Parliamentary representation, and during the course of his speech denounced the corrupt influence of the Crown, and the whole system of treasury and nomination boroughs. Under the Coalition ministry Pitt again brought forward the subject of Parliamentary Reform in a series of resolutions asserting that new measures were required to prevent bribery at elections, that boroughs should be disfranchised when the majority of voters could be found to be corrupt, and that additions should be made to the representation of the counties and the metropolis. Yet Pitt's victory at the polls was the death-blow of the movement. The demand for reform had been brought about by the fact that the influence of the Crown had caused a temporary want of coincidence between the sentiments of the House of Commons and the country and by no great idea of political representation; but now this want of coincidence has ceased to exist, the Crown has been made comparatively harmless by Burke's economical 
reform, the ministry is popular, the elections have been carried on with but little corruption, and the country is governed in substantial accordance with its wishes. The Reform Bill which Pitt introduced, contemplating the disfranchisement of thirty-six boroughs on their own application, an addition to the representation of the counties and of London, and the admission of copyholders to the franchise in the counties, was rather an attempt to put a varnish of respectability on the House than a sincere effort to make the representation of the people more complete. This really ends the first stage of the agitation for Parliamentary Reform.

At the time of the Great Reform Bill, Tories and Reformers stood face to face, each with their own theories and ideas of the Constitution; yet it has been noticed that the Tories of the time of the first two Hanoverians had been as inclined to reform abuses as the Whigs, whilst those in the early years of George III. had no clear theory of the constitution. From whence, then, did the Conservative theory come? The answer is easily given. It came from the more conservative of the Whigs, of whom Burke was the leader in political thought. Burke is in many ways the most interesting of all political theorists. He represents, on the one hand, the culmination of the Whig theory of representation, and on the other the corner-stone of Conservative theory; but to understand how these two elements came to be allied, it is necessary to understand Burke's whole theory of the Constitution. 
No one asserted more strongly than he that the true end of the legislature was to give a direction, a form, a technical dress, to the general sense of the community; that the Sovereign and House of Lords, as well as the Commons, must be regarded as only trustees for the people; that the Lower House was not intended to be a control upon the people but a control for them. He considered that in all disputes between the people and their rulers, the presumption was at least on a par in favour of the people; for they had no interest in disorder, while the governing classes had many sinister influences to determine their policy. In practice, as well as in theory, he defended the rights of the people. He was, perhaps, the first statesman who urged that lists of voters should be published in every important division, in order that the people might be able to judge of the action of their representatives. $\mathrm{He}$ advocated Parliamentary reporting, strenuously defended the right of free criticism, supported the disfranchisement of revenue officers, and was the author of one of the most comprehensive measures ever carried through Parliament for diminishing the number of those superfluous places and pensions which was one of the chief sources of its corruption; yet, in spite of this, he offered a vigorous opposition to the demand for short Parliaments, urging the horrible disorder and corruption which such a measure would produce, as well as the inevitable deterioration of the character, influence, and competence of Parliaments, that would arise from frequent changes in 
the members, and from the breaches in the continuity of public business. A Place Bill he equally disliked, as it could not fail to degrade the position of the legislature by removing from Parliament the responsible heads of the great civil departments of the army and navy, and by disconnecting from Parliamentary interest the greater part of those who held civil employment. But it is when he attacks the delegation theory of representation that his attitude becomes most clearly defined. The representative, as he told the electors of Bristol in I774, owed his constituents not his industry only, but also his judgment, and he betrayed instead of serving them if he sacrificed it to their opinion. To deliver an opinion was the right of all men, that of constituents was a weighty and respectable opinion, which a representative ought always to rejoice to hear, and which he ought most seriously to consider; but authoritative instructions, mandates which the member was bound blindly and implicitly to obey, to vote and to argue for, though contrary to the clearest conviction of his judgment and conscience, were things utterly unknown to the laws of the land, and arose from a fundamental mistake concerning the whole order and tenor of the Constitution. Parliament was not a congress of ambassadors from different and hostile interests; it was a deliberative assembly of one nation with one interest, that of the whole, where not local purposes, not local prejudices ousht to guide, but the general good resulting from the general reason of the whole. And here he 
brings out the idea expressed in almost the same words by Algernon Sydney and Sir W. Yonge. 'You choose a member indeed, but when you have chosen him, he is not a member for Bristol; he is a member of Parliament.' This speech at Bristol gives the clearest indication as to Burke's ideas of political representation which can be found in his writings, and it gives an indication of the reason for his opposition to all measures of Parliamentary Reform. The fact is, that though he wishes the House of Commons to be a control for the people, yet he feels that the people, or, for that matter, the electors, are not capable to decide on the details of legislation. He wishes the general will to prevail, but he has not the slightest faithina general assembly of the people, or, for that matter, in a congress of delegates as an organ to voice that will. England, in fact, to him, as to all the Whig representation theorists, was a collection, not of individuals, but of associations or interests, and in any assembly the tendency would be for these associations to be diametrically opposed to one another; in a word, for sinister interests to prevail over the general will. From this impasse there is one means of escapethat is, through the Constitution, an institution of almost superhuman ingenuity, which exists solely to bring the general will into action and record its decrees. The Constitution, as Burke saw it, did not exist to give each man a voice in the government of the country; the general will was far too intangible to be voiced in that way; the constituencies were 
not the people, they were only representative of the people and of the various interests of the country. The fact that there were large populations in the Northern towns unrepresented in Parliament did not appeal to Burke in the least. Birmingham might have no members, but Bristol had; and Bristol, as a constituency, he considered not only as the western city of that name, but also as a representative of the trading interest of which Birmingham formed a part, and it would return not so much members for Bristol as members for that trading interest. But even so, the danger of the existence of Parliament merely as a congress of the ambassadors of rival interests must be guarded against, and to this end it is determined that it is the duty of each member to receive no instructions or mandates, to pay no more regard to the opinion of his constituents than to the opinion of any other respectable and intelligent people, and to determine his vote on each individual question as it came before him by his judgment and conscience, and in accordance with what he thought to be the national interest. Thus the Constitution was sacred to Burke as an institution in which the various interests of the country typified in the constituencies were melted and remoulded until finally they were recast in the shape of the general will, and such changes as he advocated were in the nature of cleaning the wheels of the machine rather than of any alteration in its structure. Our representation, he thought, was nearly as perfect as the necessary imperfection of human affairs and 
human creatures would allow it to be, and it should be a subject of prudent and honest use, and thankful enjoyment, and not of captious criticism or rash experiment.

It is easy to see in what Burke's fundamental mistake lay. No doubt, as opposed to the earlier Parliamentary Reformers, he was justified in refusing to assent to any structural alteration in the Constitution merely to secure the elimination of Crown interference. The Constitution had represented the country well enough in the past, and could do so again, were the means of Crown interference, in the shape of pensions and sinecures, removed; for the treasury boroughs only represented the legitimate royal interest in the House. What he failed to see was the significance of the industrial revolution which was going on, even at the time of his attack on royal influence in the Commons. No doubt he would have been the first to agree to the idea that the Constitution had developed in the past along with the development of social factors, but he did not seem to realize that society was still developing, that the importance of some interests, rapidly being undermined in the country, was overestimated in the representative system, whilst other interests rapidly growing into prominence were not represented at all. In fact, structural alterations in the constitution of the House of Commons were necessary to bring that body into harmony with the new society which was springing up in England. Burke's theory, in fact, is typical of a conservatism which, 
without being sufficiently obscurantist to regret past developments, yet looks askance at all future progress and desires nothing better than to be left in the peaceful possession of what has been already gained. It was this idea of a divine right of things as they are which was the foundation of what theory there was in the opposition to the Reform Bill.

The development of Conservative theory was naturally towards the justification of the details of a Constitution the general principles of which Burke had already defended, and as such it is well illustrated by Paley. Paley does indeed recognize that there is something which needs justification in the Constitution, and he sets out to defend it purely on its results, and on no principle of right or prescription. The members of Parliament, he would say, are as capable men and as good representatives of the people as could be selected; why, then, change a system which produces such good results? But perhaps it would be better to examine his theory, which may be taken as an example of Conservative theory more closely. Every district and province of the Empire, he says, enjoys the privilege of choosing representatives informed of its interest and circumstances, and so entitled to communicate this information to the national council, whilst, by annexing the right of voting for members of the House of Commons to different qualifications in different places, each order and profession of men in the community becomes virtually represented; thus the irregularities of the distribution of the con- 
stituencies and of the franchise are justified on the ground that they secure the virtual representation of all the districts and all the classes in the Empire. But, as one would expect, Paley lays still more weight on the quality of the men elected. The elections are so connected with the influence of landed property as to afford a certainty that a number of men of great estates will be returned to Parliament, and are also so modified that men the most eminent and successful in their professions are, on account of their wealth and position, the most likely to be sent to Parliament as representatives. These representatives will be as heterogeneous as the varying franchises by which they are elected, and the variety of interests and character among them, added to the temporary duration of their power and the change of men which each new election will produce, will prevent, on the one hand, any subjection to external dictation, and, on the other, any undue arrogation of rights as against the people. At the same time, the proceedings and debates of Parliament and the parliamentary conduct of each representative are known to the people at large, and the representative is so far dependent upon the constituent and political importance upon public favour, that a member of Parliament cannot take a more direct route to advancement in the State than that of bringing forward and supporting laws for the public welfare. Rotten boroughs may be a theoretical anomaly, but they secure the representation of property; often men of conspicuous ability sit 
for them, and, after all, it is not of much importance who elects, as long as the men most likely to know and to promote the public interest are actually returned. Paley's theory is the natural result of the use of Burke's ideas by men who were without his political genius. His central defence of the Constitution as the instrument to voice the general will is allowed to pass unobserved, and the Constitution is now used only to secure, with more or less accuracy, the representation of the various interests which both he and the Tories agreed went to make up England.

The Conservative theory only existed to oppose the efforts of a large section of people, who, for want of a better name, may be called the Reformers, a term which includes Whigs, Radicals, Revolutionists and Utilitarians, each of whom have a separate motive for attacking the constitution as it then existed, and a separate theory with which they might attack it; but it is not proposed to deal separately with these ideas, and for the purposes of this essay two divisions will suffice-Whig and Radical.

The Liberal Whig theory may be considered, curiously enough, to start from Blackstone; curiously, that is, in view of the general impression of Blackstone which Bentham's criticism has left, but a very cursory view of his theory of the Constitution will be enough to show that he is not as conservative as he is made out to be, although, from the nature of the Commentaries, he was obliged to occupy himself chiefly with the theory of the Constitution 
as it then was. The Commons, he says, consist of all such men of any property in the kingdom as have not seats in the House of Lords, every one of whom has a voice in Parliament either personally or by his representatives, for in a free State every man who is supposed to be a free agent ought to be in some measure his own governor. The reason for a property qualification for electors is that such persons may be excluded as are in so mean a situation as to have no will of their own; for if these persons had votes they would be tempted to dispose of them under some undue influence, such as that of a great or wealthy man, who would thereby gain a larger share in elections than is consistent with the general liberty. If it were probable that every man would give his vote freely and without reference to any external pressure, then upon the true theory and principle of liberty, every member of the community, however poor, ought to have a vote in electing those delegates to whose charge is committed his property, his liberty, and his life; but as this can hardly be expected in persons of indigent fortunes or in those who are under the immeaiiate control of others, all popular States have been obliged to establish certain qualifications, whereby some who are suspected to have no will of their own are excluded from voting in order to set the more independent members of society on an equality one with the other. Only such are excluded as have no will of their own, for there is hardly a free agent to be found who is not entitled to a vote in some place or other in the king- 
dom, and although the richest man has only one vote at one place, yet if his property be at all diffused, he will have a right to vote at more places than one, and so will have many representatives. So much for Blackstone's ideas on the franchise; yet at the end there comes the startling admission that though this is the spirit of the Constitution, it is not so perfect in practice, and if any alteration could be wished in the frame of Parliaments, it would be in the direction of a more complete representation of the people; and again, though he thinks that the knights of the shire are the representatives of the landholding interest, and the boroughs of the trading interest, the idea of interests takes quite a subordinate place in his theory, and he considers that it was a mistake of the Crown to continue to summon members from the deserted boroughs and not to summon them from the newer towns. On the question of the relation of members to their constituents, however, he is as clear and decided as Burke himself. Although the representatives are chosen by a number of minute and separate districts, and each member by a particular constituency, yet when elected and returned, they serve for the whole realm; for the end of their coming thither is not particular but general, not barely to advantage their constituents but the commonwealth, and therefore they are not like deputies in the United Provinces, bound to consult with or to take the advice of their constituents on any particular point unless they themselves think it advisable to do so. Black= 
stone thus puts forward the more important ideas which influenced the Whig Reformers. Their main idea was to restore the old spirit of the Constitution and to secure a better representation for the people; but they felt that after the removal of the anomalies of the representative system this end would be best obtained by limiting the franchise to that section of the community which, by its possession of property, was comparatively independent of external influence; and again, although they clung to the theory of the representative character of members, they were very little affected by the idea of interests. In this connection it is interesting to notice how much both Blackstone and the Whig Reformers had been anticipated by Shaftesbury, who also postulates the democratic spirit of the Constitution, and wishes to restore it by abolishing rotten boroughs, and by insisting on a large property qualification.

Reason has been given why the first Parliamentary Reformers are not included among the Liberal and Reforming Whigs; their idea was merely to eliminate the influence of the Crown, and when this was effected, they ceased to agitate for reform. When Pitt's Bill failed, however, the cause of reform was taken up by Flood, who, in I790, on introducing a motion to add 100 members elected by the resident householders of the counties, made a speech which definitely points to Liberal Whig ideas. Though he still uses the danger of Crown interference as an argument for reform, the main point in his speech is that, as then constituted, apart from any external in- 
fluence, the House of Commons did not represent the people. The real remedy was to put more influence into the hands of the middle class, a class which, although very feebly represented in English politics, was yet more likely than any other to exercise political power, soberly, honestly, and independently. Property might, indeed, be a necessary ingredient in elective power-that is to say, the franchise should not go beyond property, but at the same time it should be as nearly commensurate with it as possible-and an increase in the number of constituents was a necessity to the spirit of liberty. Much the same ideas were behind the "Society of the Friends of the People,' who for so long during the period of the repression of revolutionary ideas, and the vigorous hostility of almost the whole nation, kept the flag of moderate Parliamentary Reform flying. In I793 two petitions were presented. One, from Birmingham, attacking influenceand corruption, and denouncing a system whereby members were returned to Parliament who had no real warrant to represent the people, declared that the House of Commons ought to be freely elected by the commons of England; the other, from the Friends of the People, complained that the House of Commons did not represent the people, and that its unrepresentative character constituted a grievance which ought to be redressed. The representation, it said, was disproportionate, and the franchise was based upon no principle of right. In I795 the Friends of the People adopted and published a plan of reform which 
recommended that every tax-paying householder should vote in an election for one member, that elections should all be held on one day, that wages should be paid to members from the general revenue, and that the duration of Parliaments should be shortened. And in connection with this may be taken some remarks of Charles James Fox, who, although he was not a member of the Society, yet sympathized very strongly with its objects. He said that it was demonstrated beyond the power of subterfuge to question that genuine representation could alone give solid power, and that for the Government to be made strong it was necessary for the people to make the Government. He deprecated universal suffrage on account of a supposed want of independence in the voters, and thought that the best plan was that by which the greatest number of independent voters should be brought into action; meanwhile, by making the people of England a constituent part of the Government of England, nothing more would be effected than the restoration of the ancient edifice designed and framed by our ancestors. From the Friends of the People and Charles James Fox, the moderate reforming movement of the Liberal Whigs passes under the leadership of Lord John Russell, whose successive resolutions kept the movement before Parliament until it reached its consummation in I832.

But if we look for any great idea of political representation which led the Whig Reformers to attack 
the existing condition of things, and in accordance with which they formulated their plan of reform, the search will be in vain. Much as it has been said, though perhaps rather unjustly, of the barons who forced Magna Charta upon John, that they were guided, not by any great ideas of liberty or constitutional progress, but by a number of small and very practical motives, so it might be said of the men who forced the Reform Bill on the House of Lords, that their object was to remedy some very obvious and very practical abuses, and not to bring the Constitution into agreement with any particular principle of right. 'I am at a loss,' said a member of the Tory party, "to perceive the general principle on which our reforming cabinet have proceeded; they might have taken for their basis of representation, property, taxation, or population, but they have selected neither.' He might well be at a loss; therewas no general principle on which the Reformers could be said to act. On the one hand they clung to the idea of the representative character of members and refused to do anything to minimize it by shortening the duration of Parliament; on the other, they dropped the idea of interests on which, from the time of Algernon Sydney, the Whig representative theory had been based. On the one hand they put forward the idea of Reform as necessary to secure the representation of the people, and on the other they limited the application in practice of this principle by a fairly large property qualification on the merely practical ground that property was 
necessary to secure the independence of the voter. Two considerations, however, will partially explain the theory of the Reform Bill. The Reformers did not regard themselves as innovators in any sense of the term, but as the restorers of the old spirit of the Constitution, enveloped and lost amidst the accretions and impurities which had grown up around it, and which they wished to remove, and their main idea was the representation of the middle class. It is no doubt disappointing to a writer on ideas on political representation not to be able to explain such an important epoch in the history of the representative system as that of the Reform Bill in the light and growth of the development and ultimate success of some great idea; but the fact remains that the abolition of the abuses of the old system was not due to any such idea, and that what theory there was, was merely invented by the Reformers to justify their reforms.

The Radical ideas of political representation have up to now been omitted, somewhat unjustifiably perhaps, in view of the fact that the Radicals unquestionably had some influence on the Whig Reformers; but nevertheless Radical thinkers are essentially different from those of the two great political parties; they desire neither to maintain nor to reform the representative system, but to revolutionize it. The birth, or, as one would prefer to call it, the resurrection of Radicalism, is generally traced to the year 1769 , the year of the formation of the great democratic society of the Bill of Rights, a fact which 
strikingly illustrates the real change in political opinions, which takes place in response to the change in political conditions about I760. Under the auspices of this society a long series of tests were prepared to be offered to candidates at elections, and among other things every candidate was required to aim at a full and equal representation of the people in Parliament, annual Parliaments, and the exclusion from the House of Commons of every member who accepted any place or pension. One of the leading doctrines of the new society was that a member of Parliament was simply a delegate, who must regulate his political career entirely according to the wishes of his constituents, and at a great meeting of February, I769, Beckford declared that if he received instructions from his constituents directing him to take a course opposed to his convictions, he would consider himself bound to conform to their desires, and would not oppose his judgment to that of some 6,000 of his fellow-citizens. So great an influence had the society that the habit of sending instructions to members became very popular among the constituencies, and it was this as much as anything which caused Burke's famous declaration at Bristol in I774. The formation of the society was very largely due to the resentment felt at the action of the House of Commons on the question of the Middlesex election, and Wiikes was one of its most prominent members and its voice in Parliament. In accordance with this capacity, in I776 he moved for leave to bring in a Bill for the 
just and equal representation of the people in Parliament, and the speech in which he supported the resolution, besides being an important declaration of representative principles, points to the fact that English Radicals, before they were affected by Revolutionary ideas, had a sober and intelligent policy. What they wanted, as Wilkes put it, was an English Parliament, to speak the free and unbiassed sense of the body of English people and of every man in the community. The meanest mechanic, the poorest peasant and daý-labourer, had important rights respecting his personal liberty, that of his wife and children, and his property, however inconsiderable. 'Poor as well as rich, men of great estate and men of none, should have a share in making the laws which affect their lives and happiness,' and to effect this Wilkes proposed to give a free vote to every free agent, to disfranchise rotten boroughs, to enfranchise the newer towns, and to arrange shorter Parliaments, and a Place and Pension Bill. Radicalism is often said to be based on the idea of the fundamental rights of individuals; but this is not the case with the early Radicals, and their point of view, as expressed by Cartwright, that the greatest possible stake in the country is not wealth and property but wife and children, however revolutionary it may have been when it was first propounded, seems in these more enlightened days eminently reasonable and intelligent, and what really distinguishes them from the Whig Reformers is the comprehensiveness of their schemes, which imply 
not only a desire to reform abuses, but a definite democratic theory on which the reform was to be based. But the advent of revolutionary ideas changed Radicalism for the worse. Parliamentary Reform was lost sight of as a lesser change, which the greater, the securing of sovereignty to the people, would necessarily involve, and thus the Radicals lost touch with practical politics and with the real political opinion of the country. Sweeping motions of reform, such as that of the Duke of Richmond, involving annual Parliaments and manhood suffrage, were all that they would tolerate. There is consequently little importance to be attached to their ideas of political representation, even if they can be said to have had any. 'What is government,' says Paine, 'more than a management of the affairs of the nation?' 'However it may have been usurped, it is not, and from its nature cannot be, the property of any particular man or family, but of the whole community; so that the nation has an inherent right to abolish any government that it finds inconvenient, and to establish such as accords with its interest.' Paine himself, though an ardent advocate of regularity in the franchise and in the size of the electoral districts, did not go to the extremes of democracy, and was inclined to think that the government which the nation would find most to its interest was one in which the franchise was limited by a small property qualification, and members of Parliament held something of a representative character; but he was almost alone 
in his conservatism, and demands for universal suffrage, annual Parliaments, and delegates, from the various revolutionary societies, meet one with wearisome iteration. The influence of this style of thought on England and on English political life does not seem to have been large, and, after the policy of repression was inaugurated by Pitt's ministry, became practically non-existent. The Radicalism which survives is of the earlier kind, although no doubt tinged and influenced to some considerable extent by revolutionary ideas and reinforced by thinkers of another school.

This other school is the school of Bentham, and the philosophical Radicals. Bentham himself was primarily a legal reformer, and it was only when he discovered, somewhat to his own astonishment, that his ideas on legal reform were not going to be accepted, that he realized the strength of Conservatism in the country, and turned to attack it by means of Parliamentary Reform. Thus, in his Plan of Parliamentary Reform, and still more in James Mill's 'Essay on Government' in the Encyclopadia Britannica, there appears a complete view of the ideas of the philosophical Radicals on political representation. They start from two primary principles-the self-preference principle, in virtue of which each man will desire and seek after his own greatest happiness, and the 'greatest happiness' principle, in virtue of which the right and proper end of government is the greatest happiness of the greatest number. The deduction from these two principles 
is quite obvious. The actual end of any Government will be the happiness of the governors; of an aristocratical Government, the happiness of the aristocracy; of a monarchical Government, the happiness of the monarch; and thus, to secure the greatest happiness of the greatest number it is only necessary to provide for the Government of all, and so to procure an identity of interest between governors and governed. In this way they more or less assumed that there was such a thing as an average man, who would form an independent opinion upon legislative questions, vote for men who would apply his opinions, and see that his representatives performed his bidding honestly. The people will always know their own interests, and will naturally choose morally apt agents, whilst men who wish to be chosen will desire truly to become morally apt, for they can only recommend themselves by showing their desire to serve the general. Thus, democracy being once established, with its paraphernalia of universal suffrage, annual Parliaments and deputies, there is no necessity to inquire further in the matter, for the Constitution will work exactly as it is intended to; and that there should be any need to inquire into the social instincts which lie behind all political action does not occur to them for a moment. In this respect, indeed, Bentham shows considerable inconsistency when, in his fear of the corruption of delegates, he inserts a provision that members are not to be re-eligible until after an interval; for, on his own showing, such corruption was impossible; 
but in another direction he was inclined to carry out his theory to its logical conclusion, and after discussing the question of female suffrage, he leaves it undecided and refuses to pronounce against it. An agreement was arrived at between the ordinary Radicals and the Benthamites, and voiced in Sir Francis Burdett's resolutions of $18 \mathrm{I} 8$. The preamble contained the proposition that no adequate security for good government can have place but by means of, and in proportion to, a community of interest between the governors and the governed, and the resolutions embody demands for a free and comprehensive suffrage, equal electoral districts, and annual Parliaments, although Burdett himself did not believe in the delegation principle. Naturally there was no Radical thought in favour of the Reform Bill, and on the eve of it in I83I a paper is issued, the forecast of the people's charter, which states the views of the extremists. It is practically a declaration of the rights of man. All men are born equally free and have certain natural inherent and inalienable rights; every man who is twenty-one years of age, who is of sound mind, and is not tainted by crime, has a right, either by himself or by his representative, to a free voice in determining the necessity and incidents of public contributions; the method of voting should be by ballot, and intellectual fitness and moral worth, rather than property, should be the qualification of representatives. And so we leave the Radicals looking beyond the Reform Bill to later developments in the Constitu- 
CONCLUSIOA

tion in which their ideas have been or are being realized.

As the English Constitution proceeded and developed in an orderly manner, so ideas of political representation which follow it closely through its course, proceed and develop. What break there is to be found in the development of either-and it is idle to deny that the 'legal revolution' of the Reform Bill is such a break-is mainly due to causes, the origin of which are not to be found in England, and it is in the French Revolution rather than in the English aristocracy that the reason for that 'legal revolution' will be found. Throughout the period the practical nature of English theory is strongly in evidence, and there is little attempt to reform Parliament by the application of any abstract principle of right. Whilst, on the one hand, the Conservatives take their stand in defence of the Constitution on the ground of the excellence of the results, the Liberals turn rather to the idea of restoring to it its original spirit, and wish to bring the Parliament once again into accordance with the idea which Sir Thomas Smith expressed so well in the days of Elizabeth. 'For every Englishman is intended to be there present, either in person or by procuration and attorneys, of what pre-eminence, state, dignity or quality soever he be, from the prince, be he King or Queen, to the lowest person of England. And the consent of Parliament is taken to be every man's consent.' It is on this idea that the Reformers, 
from Shaftesbury to Lord John Russell, base their argument, and it is to this conception that, in spite of their illogicality and inconsistency, they are always working back.

\section{BIBLIOGRAPHY.}

The following are the more important references to the subject:

\section{Modern Works.}

Veitch: Genesis of Parliamentary Reform.

PORRITT: The Unreformed House of Commons.

LECKY: England in the Eighteenth Century.

Gooch: English Democratic Ideas in the Sixteenth Century.

LESLIE STEPHEN: English Utilitarians.

Kent: English Radicals.

\section{Tracts, Pamphlets, Speeches, etc.}

Parliamentary Debates, especially on the Septennial Act and the motion for its repeal in I734, also on Parliamentary Reform after I 760 , although the greater part of the immense mass of matter on the subject is of little value.

Somers Tracts, for Shaftesbury's paper.

Tracts of William III., for Jura Populi Anglicani.

Burke's Speeches, especially that of I774 at Bristol.

DEFOE: Original Power of the People of England.

\section{Original Works.}

Locke: Second Treatise on Civil Government.

LOCKE: Constitutions of Carolina.

SYDNEY: Discourse on Government.

Swift: Essay on Public Absurdities.

Blackstone: Commentaries.

BuRKE: Thoughts on the Present Discontents.

BURKE: Reflections on the French Revolution.

PAINE: Rights of Man.

PALEY: Moral and Political Philosophy.

Bentham: Fragment on Government.

Bentham: Plan of Parliamentary Reform.

JAMEs Mill: Essay on Government (Encyclopadia Britannica, edition of 1820$)$. 


\section{F 14 DAY USE}

Sir I LOAN DEPT.

I $\mathrm{He}$ This book is due on the last date stamped below, or on the date to which renewed.
LITE.

Impe

'So

that o

earlier

THE

The

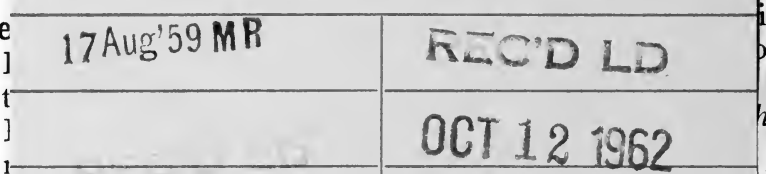

So

The
$\vdots$
'Al $g r$ '
$T H E$
An ?

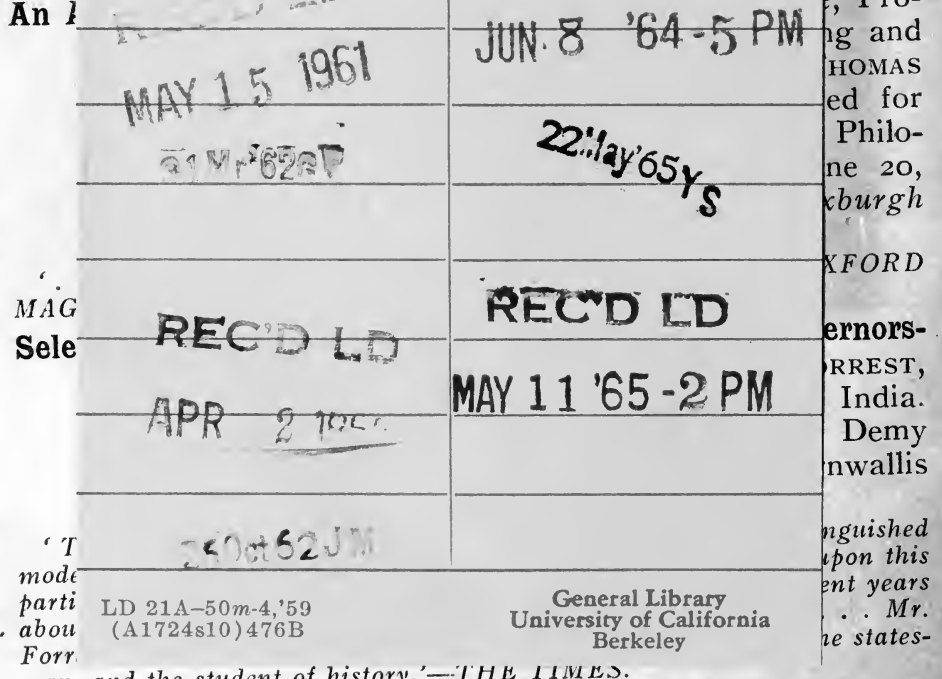

man, and the student of history. -THE 11MED.

Oxford Prize Compositions. Published by B. H. BLACKWELL. Complete List post free on application.

BROAD STREET, OXFORD 


\section{YB 08516}




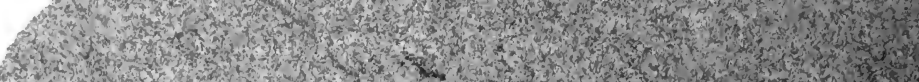

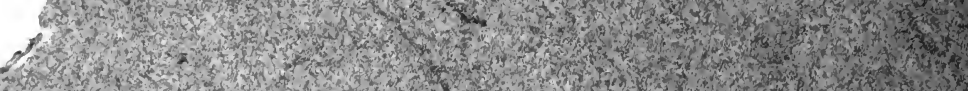

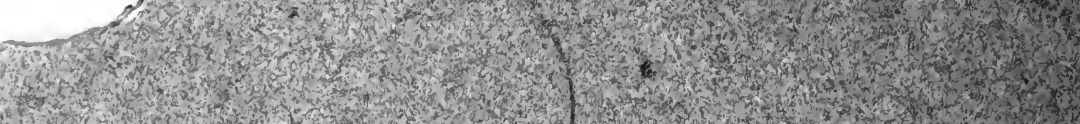

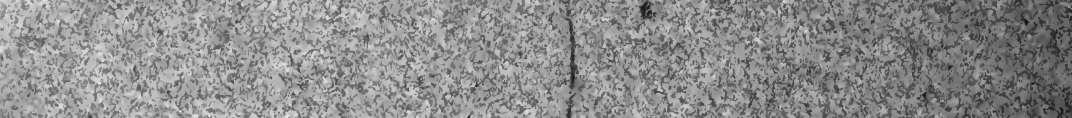

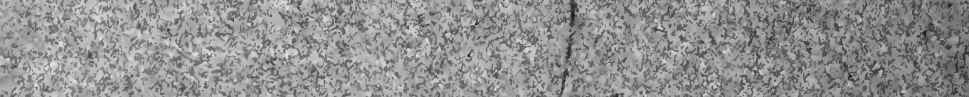

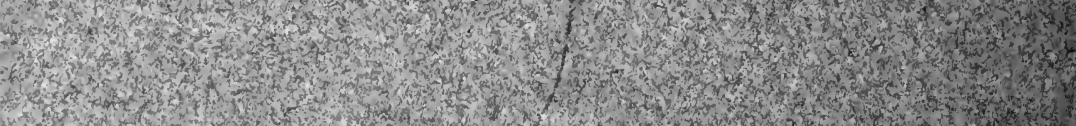
ex.

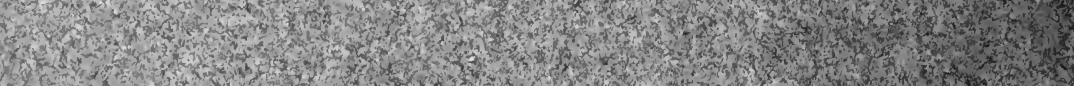

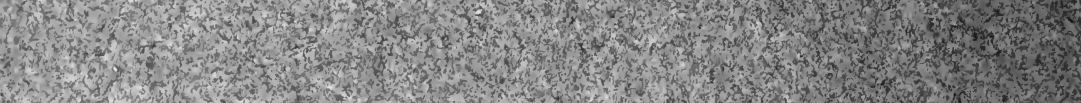

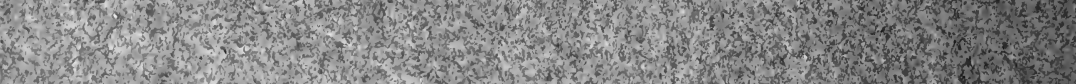

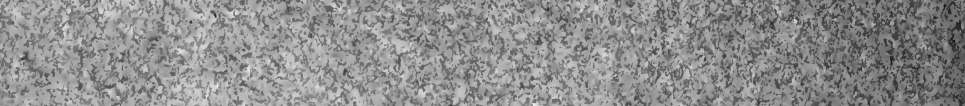
-

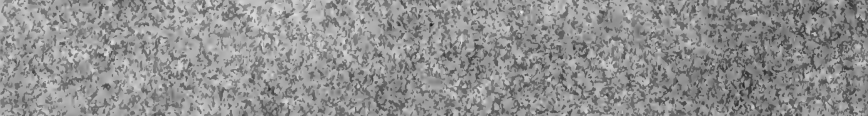

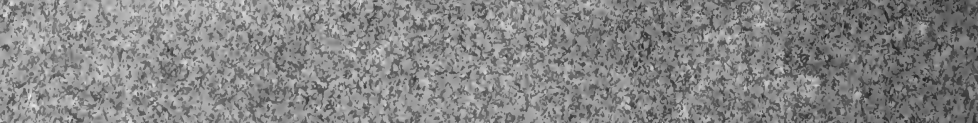
(2)

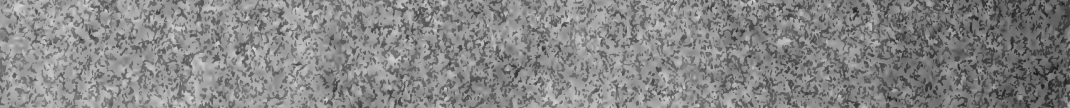

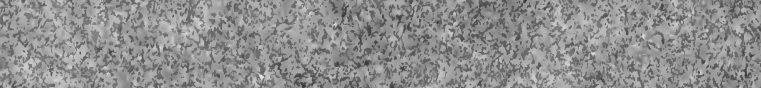

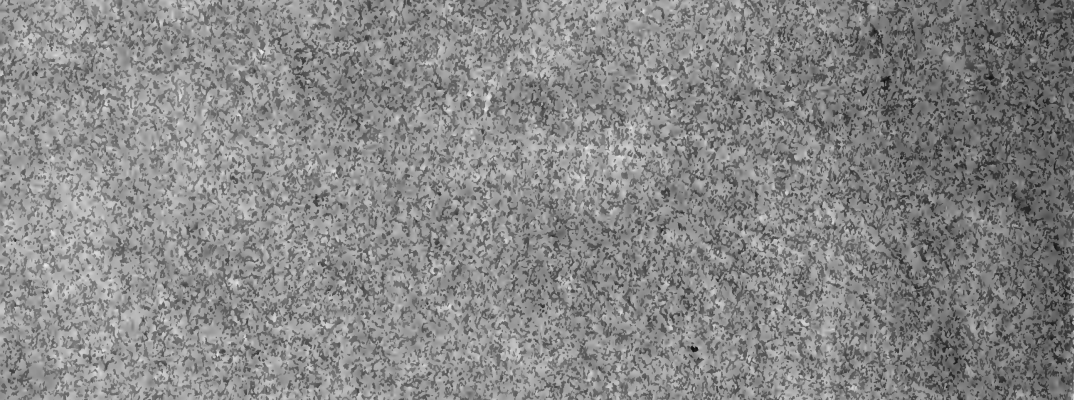

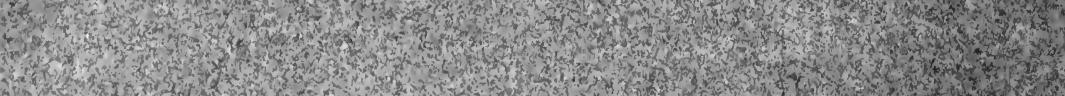

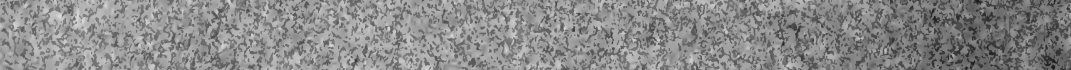

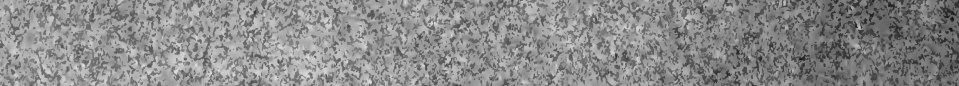

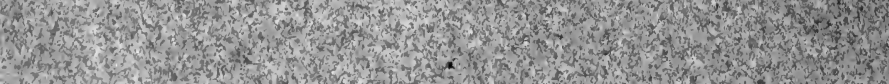

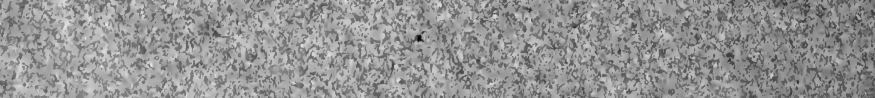

